\title{
Sustainable Design of Biorefinery Processes on Cocoa Pod: Optimization of Pectin Extraction Process with Variations of $\mathrm{pH}$, Temperature, and Time
}

\author{
Desniorita $^{\# *}$, Novizar Nazir ${ }^{+}$, Novelina ${ }^{+}$, Kesuma Sayuti $^{+}$ \\ "Postgraduates Program, Andalas University, Padang, Indonesia \\ E-mail :*desniorita@gmail.com
}

${ }^{+}$Faculty of Agricultural Technology, Andalas University, Padang, Indonesia

\begin{abstract}
Pectin is a polysaccharide compound, which is a D-galacturonic acid polymer that is connected by $\alpha-1-4$ glycosidic bonds. Pectin can be extracted from the cocoa pod. This research is part of research on the Sustainable Design of biorefinery processes of cocoa pod. The aim of this research were to extract pectin from cocoa pod by optimizing $\mathrm{pH}$, temperature and time. The response from this study was the yield, pectin content and methoxyl content. This research used the Surface Response Methodology (RSM) with the center point obtained was $\mathrm{pH} 2.5$, temperature $95{ }^{\circ} \mathrm{C}$ and time was 3 hours. The treatment consisted of $\mathrm{pH}$, temperature, time, and the expected response was the results of pectin, pectin content, and methoxyl content. The result showed that the pH, temperature and extraction time of cocoa pod had significant effect to the yield of pectin, pectin content and methoxyl content. The optimum conditions for the extraction of pectin were $\mathrm{pH}$ of 2 , temperature of $95{ }^{\circ} \mathrm{C}$ and extraction time of 3 hours with a predicted yield of pectin of $2.33 \%$, pectin content of $44.39 \%$ and methoxyl content of $7.07 \%$. The functional groups between the standard pectin and the cocoa pod pectin are not significantly different. They have the same variety of functional groups. This data supports that the extracted pectin has the same structure with standard pectin which is shown in the IR spectrum of of FTIR test.
\end{abstract}

Keywords - pectin; extraction; cocoa pod; optimization; biorefinery.

\section{INTRODUCTION}

Cocoa pod is an agricultural waste that has not been exploited to its full potential. Cocoa pod is left over from processing the fruit of cacao (Theobroma cacao $L$ ). With the increasing production of processed cocoa fruit, it will cause an increase in cocoa pod waste which will cause problems to the environment. To prevent cocoa pod waste become an environmental problem, then it should be processed optimally [1]. The cocoa pod can be processed, resulting in a wide range of agro raw materials such as pectin, lignin, cellulose and other raw materials. If the cocoa plant increased, the cocoa fruit production will also increase. The cocoa pod processing would be beneficial and can produce raw materials that can be utilized by agroindustry. One of the methods of cocoa pod utilization is the extraction pectin which contained in the pod [2].

Optimal pectin extraction can be carried out using the Response Surface Methodology (RSM) method with Central Composite Design (CCD). The surface response method (RSM) is used to determine the optimum conditions of various factors to be studied. Optimization with RSM is better than conventional methods. The advantage of the RSM method is that it does not spend much time and cost, because, with the response method does not require much data, the results are delivered in the form of graphical summaries and contour plots that are easy to understand in the extraction treatment conditions how much pectin [3], [4]

Pectin is a solid, brownish. Physical properties of pectin depending on the chemical characteristics of the pectin, such as solubility, viscosity and its ability to form a gel. The quality and content of pectin from various plants are not the same, depending on the source of raw materials, the treatment, of maturity levels, and climate at the time of taking the raw materials [5]. Pectin is one of the compounds found in some plant cell walls. Pectin is a polysaccharide that is a polymer of D-galacturonic acid that are linked by of $\alpha-1-4$ glycosidic bonds. Part of the carboxyl group on pectin compounds undergo esterification into methoxyl. This compound is called pectinate acid or pectin [6]. Pectinate acid with sugar and acids at high temperature will form a gel. The rate of esterification on pectin varies, depending on the source of its pectin. This esterification level will influence the solubility and the quality of pectin [7]. 
Pectin can be used as a thickening, gel-forming agent, as emulsifiers and stabilizers on the food industry. Pectin can also be utilized for a blender of drugs and cosmetics [7], [8]. Pectin sources are very widely available, but it has not been produced to its full potential. Currently, the needs of pectin in Indonesia have not been fulfilled. Import data of pectin in Indonesia for the year 2016 is as much as $240,792 \mathrm{~kg}$. Cocoa pods can be used as a source of pectin. Cocoa fruit will produce about $75 \%$ of the skin. If it is not utilized, the cocoa pod will build up and will cause problems for the environment. Pectin is produced from the cocoa pod utilizing extraction [9].

The process of pectin extraction is simple. The extraction process is the process of separation of one or more ingredients of a solid or liquid in the tissues of plants. Some methods of extraction are maceration, percolation, soxhlet extraction, and more. Pectin extraction process using a solvent. The quality of the extraction result is influenced by the techniques of extraction, the extraction time, temperature, solvent type, solvent concentration and comparison of materials with solvent [10]. The extraction of pectin is usually done in acidic conditions because at this condition, protopectin will be hydrolyzed into pectin [11]. Some researchers have done the extraction of pectin. The extraction of pectin will be influenced by the $\mathrm{pH}$, temperature and reaction time [7], [12] - [14], which were conducted on optimization of the pectin extraction process at various $\mathrm{pH}$, temperature and time. This research is part of the sustainable design of biorefinery processes studies of a cocoa pod. The research aimed to get the optimum conditions for pectin extraction from the cocoa pod.

\section{MATERIAL AND METHOD}

\section{A. Material}

The materials used are cocoa skin of Ferestero variety, anhydrous citric acid, $\mathrm{NaOH} 0,1 \mathrm{~N}$, phenolphthalein, alcohol $95 \%, \mathrm{NaOH} 0,05 \mathrm{~N}, \mathrm{HCL} 0,25 \mathrm{~N}$, red phenol indicator, and distilled water.

\section{B. Apparatus}

Apparatus used in this study: Erlenmeyer 100, 500, 1000 $\mathrm{ml}$, goblet, water bath, drying oven, blender and rotary evaporator

\section{Research Design}

The study was conducted using Responses Surface Methodology (RSM), with Central Composite Design. There are three independent variables, namely $\mathrm{X}_{1}(\mathrm{pH}), \mathrm{X}_{2}$ (temperature) and $\mathrm{X}_{3}$ (time). The expected Responses are to yield $\left(\mathrm{Y}_{1}\right)$, pectin content $\left(\mathrm{Y}_{2}\right)$ and methoxyl content $\left(\mathrm{Y}_{3}\right)$. The center point or midpoint of the RSM is determined by optimizing the extraction of cocoa pod pectin using Taguchi Orthogonal Array L. Optimization of cocoa pod pectin extract with Taguchi is carried out at $\mathrm{pH} 2.5,95^{\circ} \mathrm{C}$ and 3 hours [14]. From the processed optimization of pectin extraction with Taguchi obtained optimal results at $\mathrm{pH} 2.5$, temperature $90^{\circ} \mathrm{C}$ and time 3.5 hours, and it is used for the design of RSM in the study. The design of the RSM is made at $\mathrm{pH} 2 ; 2.5 ; 3$, temperature $85^{\circ} \mathrm{C} ; 90^{\circ} \mathrm{C} ; 95^{\circ} \mathrm{C}$, and time 3 hours, 3.5 hours, 4 hours.

\section{Research Process}

The study was conducted in advance to determine the RSM center point of cocoa pod extraction using Taguchi Orthogonal Array $L$ on three parameters, i.e. on variations of $\mathrm{pH} 2 ; 2.5 ; 3,90^{\circ} \mathrm{C}$ temperature; $95^{\circ} \mathrm{C} ; 100^{\circ} \mathrm{C}$, and time 2.5 hours, 3 hours and 3.5 hours [14]. The results of the study with Taguchi Orthogonal Array L, which are $\mathrm{pH} 2.5$, temperature $90^{\circ} \mathrm{C}$, and time of 3.5 hours are used as a center point of the Responses surface methodology (RSM) design of cocoa pod pectin extraction.

\section{E. Pectin Extraction Process}

Pectin extraction was carried out using a mixture of water and citric acid. The cocoa pod that has been separated from the fruit is cut into small pieces with a size of about $1 \times 2 \mathrm{~cm}$. Next, cocoa pod mixed with water, with ratio $1: 4$, mashed to form a cocoa pod pulp, then added citric acid according to the desired $\mathrm{pH}$. Next, the cocoa pod pulp is heated in a water bath according to the temperature and the heating time of the research design. After heating, it is separated with a filter and the filtrate is collected. The filtered results is thickened by heating it at $60^{\circ} \mathrm{C}$ for 150 minutes with a rotary vacuum evaporator until thick, and the remaining volume is approximately half of its initial volume. To separate the pectin from the solvent, the precipitation was carried out by adding 96\% alcohol in a ratio of 1: 2 and left overnight to form a precipitate. The formed precipitate was filtered with a $60 \mathrm{~T}$ screen cloth, then the precipitate is washed with alcohol $96 \%$ until it reached a neutral $\mathrm{pH}$. Furthermore, drying is carried out at $40-50{ }^{\circ} \mathrm{C}$ for 10 hours, and then pectin is obtained from the pod of cocoa.

The obtained pectin is mashed and sieved until it passed the 80-mesh sieve for analysis. Analysis of pectin extract was carried out on the pectin yield, pectin content and methoxyl content [7]. Initial analysis was also carried out on raw materials. There is water content, ash content, levels of extractive substances, cellulose content and pectin content [15].

\section{RESULTS AND DISCUSSION}

\section{A. Raw Material}

The chemical analysis result of cocoa pod raw material is shown in Table 1.

TABLE I

The Result of Chemical AnAlysis of CACAO PoD

\begin{tabular}{|l|l|}
\hline \multicolumn{1}{|c|}{ Parameter } & Content (\%) \\
\hline Water content & 82.05 \\
Ash content & 1.50 \\
Extractive Substance Levels & 1.29 \\
Holocellulose & 57.67 \\
Cellulose & 40.10 \\
Lignin & 22.00 \\
Pectin & 17.07 \\
Hemicellulose & 17.19 \\
\hline
\end{tabular}

From the chemical analysis of raw materials, it can be seen that the cocoa pod pectin content is quite high, which is around $17.07 \%$. That pectin content can be extracted and used as raw material for agro-industry. Pectin can be used in the food industry, namely as a thickener, emulsifier, 
stabilizer. Pectin can also be used for the pharmaceutical industry and other industries [7].

\section{B. Optimization of the Cocoa Pod Pectin Extraction Process}

The results of pectin extract analysis related to $\mathrm{pH}$, temperature and reaction time to the Responses of pectin yield, pectin content and methoxyl content from 20 run experiments can be seen in Table 2 .

TABLE II

Results of Analysis of Cocoa Pod Pectin Extracts Related to Ph, TEMPERATURE, Time To RENDEMENT RESPONSES, PECTIN CONTENT AND METHOXYL CONTENT

\begin{tabular}{|c|c|c|c|c|c|c|c|}
\hline $\bar{E}$ & $\stackrel{\Xi}{\Xi}$ & 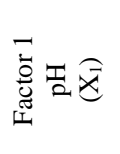 & 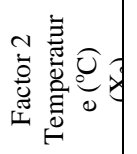 & 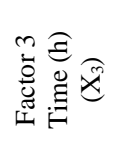 & 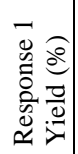 & 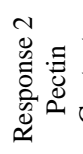 & 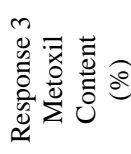 \\
\hline 14 & 1 & 2.50 & 90.00 & 4.34 & 1.42 & 20 & 5.58 \\
\hline 3 & 2 & 2.00 & 95.00 & 3.00 & 2.14 & 40 & 7.69 \\
\hline 19 & 3 & 3.00 & 95.00 & 3.00 & 2.43 & 45 & 6.23 \\
\hline 12 & 4 & 2.50 & 98.41 & 3.50 & 1.46 & 25 & 4.80 \\
\hline 8 & 5 & 3.00 & 95.00 & 4.00 & 1.71 & 35 & 4.11 \\
\hline 6 & 6 & 3.00 & 85.00 & 4.00 & 1.82 & 35 & 5.12 \\
\hline 7 & 7 & 2.00 & 95.00 & 4.00 & 1.67 & 30 & 5.46 \\
\hline 20 & 8 & 2.50 & 90.00 & 3.50 & 2.05 & 40 & 7.16 \\
\hline 1 & 9 & 2.00 & 85.00 & 3.00 & 2.26 & 45 & 6.20 \\
\hline 15 & 10 & 2.50 & 90.00 & 3.50 & 2.04 & 30 & 6.52 \\
\hline 11 & 11 & 2.50 & 81.59 & 3.50 & 2.25 & 30 & 5.86 \\
\hline 5 & 12 & 2.00 & 85.00 & 4.00 & 1.46 & 28 & 4.33 \\
\hline 13 & 13 & 2.50 & 90.00 & 2.66 & 1.97 & 26 & 6.43 \\
\hline 18 & 14 & 2.50 & 90.00 & 3.50 & 1.89 & 40 & 5.77 \\
\hline 2 & 15 & 3.00 & 85.00 & 3.00 & 1.79 & 20 & 6.04 \\
\hline 9 & 16 & 1.66 & 90.00 & 3.50 & 2.12 & 30 & 4.92 \\
\hline 17 & 17 & 3.50 & 90.00 & 2.50 & 1.34 & 10 & 4.40 \\
\hline 16 & 18 & 2.00 & 95.00 & 2.50 & 2.89 & 60 & 7.75 \\
\hline 4 & 19 & 3.00 & 95.00 & 3.00 & 2.24 & 30 & 5.27 \\
\hline 10 & 20 & 3.34 & 90.00 & 3.50 & 1.56 & 10 & 4.74 \\
\hline
\end{tabular}

Table 2 shows that pectin yield, pectin and methoxyl content are highest at the treatment of $\mathrm{pH} \mathrm{2,} \mathrm{heating}$ temperature $95^{\circ} \mathrm{C}$ and reaction time 2.5 hours. While the yield, pectin content is lowest at $\mathrm{pH} 3.5$, heating temperature $90^{\circ} \mathrm{C}$ and reaction time 2.5 . The lowest methoxyl content, is at the treatment of $\mathrm{pH} \mathrm{3}$, temperature $95^{\circ} \mathrm{C}$ and the reaction time 4 hours. The midpoint of the treatment was obtained from the initial study of pectin extraction optimization using the Taguchi Orthogonal Array L method [14], [16].

Pectin extraction is influenced by $\mathrm{pH}$, temperature and reaction time. Low $\mathrm{pH}$, long reaction time will result a higher yield and pectin content [12]. According to Ref. [7] that pectin will increase with increasing of $\mathrm{pH}$, temperature and reaction time. Increasing of pectin yield to optimal $\mathrm{pH}$, temperature and reaction times. The optimal temperature of extraction is $90^{\circ} \mathrm{C}$ pectin, $\mathrm{pH} 2$ and reaction time 2 hours. Increasing the temperature will increase the penetration of the solvent, and will increase the solubility of pectin. The increase in temperature is also affected by the length of reaction time. Likewise for $\mathrm{pH}$, the yield of pectin increases with lower $\mathrm{pH}$ because strong acids will destroy the cell wall and pectin will be released [17]. At $\mathrm{pH} 2.5$, temperature $103.4^{\circ} \mathrm{C}$ and reaction time 45 minutes get pectin around 2$4 \%$ [7].

\section{Pectin Yield}

The model obtained from the results of research on the pectin yield of cocoa pod with the Responses surface methodology (RSM) method can be seen in Table 3. The RSM model can show the relationship between $\mathrm{pH}$, temperature and extraction time of the pectin yield obtained [18].

TABLE III

RESUlTS OF ANALYSIS OF VARIANCE (ANOVA) OF YIELD RESPONSE

\begin{tabular}{|l|r|r|r|r|r|r|}
\hline Source & $\begin{array}{r}\text { Sum of } \\
\text { Square }\end{array}$ & Df & $\begin{array}{r}\text { Mean } \\
\text { Square }\end{array}$ & $\begin{array}{r}\mathrm{F} \\
\text { Value }\end{array}$ & $\begin{array}{r}\mathrm{p}- \\
\text { Value } \\
\text { Prob>F }\end{array}$ & \\
\hline Model & 1.99 & 6 & 0.33 & 4.45 & 0.0106 & Significant \\
A-pH & 0.076 & 1 & 0.07 & 1.04 & 0.3266 & \\
B-Suhu & 0.013 & 1 & 0.013 & 0.18 & 0.6803 & \\
C-Waktu & 0.83 & 1 & 0.83 & 11.43 & 0.0049 & \\
AB & 0.050 & 1 & 0.050 & 0.69 & 0.4212 & \\
AC & 0.54 & 1 & 0.54 & 7.43 & 0.0173 & \\
BC & 0.11 & 1 & 0.11 & 1.52 & 0.2399 & \\
Residual & 0.95 & 13 & 0.073 & & & Not \\
Lack of & 0.91 & 10 & 0.091 & 7.92 & 0.0576 & significant \\
Fit & 0.034 & 3 & 0.011 & & & \\
Pure & 2.93 & 19 & & & & \\
Error & & & & & & \\
Cor & & & & & & \\
Total & & & & & & \\
\hline
\end{tabular}

The ANOVA results show that the overall model is significant at a $5 \%$ significance level. The calculated $\mathrm{F}$ value is 4.55 which indicates that the model is significant for the pectin yield. Of the three factors, which significantly affect the pectin yield is the reaction time factor. While $\mathrm{pH}$ and temperature factors have no significant effect on the yield. It is shown in the model the existence of significant effect interaction of $\mathrm{pH}$ factor and reaction time to pectin yield produced. Extraction time and temperature will affect the pectin yield. The higher the temperature and the longer the extraction time will increase the yield of pectin, to a certain extent [2]. The higher the temperature will increase solvent penetration, so do with reaction time. For $\mathrm{pH}$, the lower the $\mathrm{pH}$, the pectin will be more easily separated from the cell wall [17]. Statistical results of cocoa pod extraction for the pectin yield by the RSM method can be seen in Table 4 .

TABLE IV

STATISTICAL MODEL OF COCOA POD EXTRACTION FOR THE RSM PROGRAM PECTIN YIELD

\begin{tabular}{|l|r|r|r|r|r|r|}
\hline Source & $\begin{array}{r}\text { Std. } \\
\text { Dev }\end{array}$ & Squared & $\begin{array}{r}\text { R- } \\
\text { d R- } \\
\text { Squared }\end{array}$ & $\begin{array}{r}\text { Predicte } \\
\text { d R- } \\
\text { Squared }\end{array}$ & Press & \\
\hline Linier & 033 & 0.4106 & 0.3001 & -0.0717 & 3.14 & \\
2FI & $\underline{0.27}$ & $\underline{0.6775}$ & $\underline{0.5286}$ & $\underline{0.0341}$ & $\underline{2.83}$ & Suggested \\
Quadrati & 0.29 & 0.7037 & 0.4370 & -0.4583 & 4.27 & Aliased \\
c & 0.14 & 0.9737 & 0.8753 & & + & \\
Cubic & & & & & & \\
\hline
\end{tabular}

Table 3 shows that among the existing models, linear, 2FI, quadratic, cubic that are suggested to be used is 2FI. This research was conducted in parallel with the optimization of $\mathrm{pH}$, temperature and reaction time. From the research that has been done on the combined optimization of cocoa pod extraction at different $\mathrm{pH}$, temperature and time to obtain the selected pectin yield, the selected statistical model is $2 \mathrm{FI}$. The 2FI model was chosen after the maximization selection 
solution on the program and on the value of Adjusted $R$ Squared and Predicted R-Squared. To get the pectin yield equation from pectin extraction research with optimization of $\mathrm{pH}$, temperature and time, the Responses surface methodology method is used. The equation is:

$$
\begin{aligned}
Y_{i}= & 3.6881-5.00722 X_{1}+0.063047 X_{2}+1.60851 X_{3}+ \\
& 0.029051 X_{1} X_{2}+0.64347 X_{1} X_{3}-0.040458 X_{2} X_{3}
\end{aligned}
$$

Figure 1 can be seen the relationship between the actual and predicted values of the pectin yield. Note: $\mathrm{Y} 1=$ pectin yield, $\mathrm{X} 1=\mathrm{pH}, \mathrm{X} 2=$ temperature, $\mathrm{X} 3=$ Time

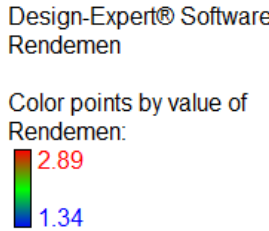

Design-Expert® Software

Color points by value of

Rendemen:

1.34

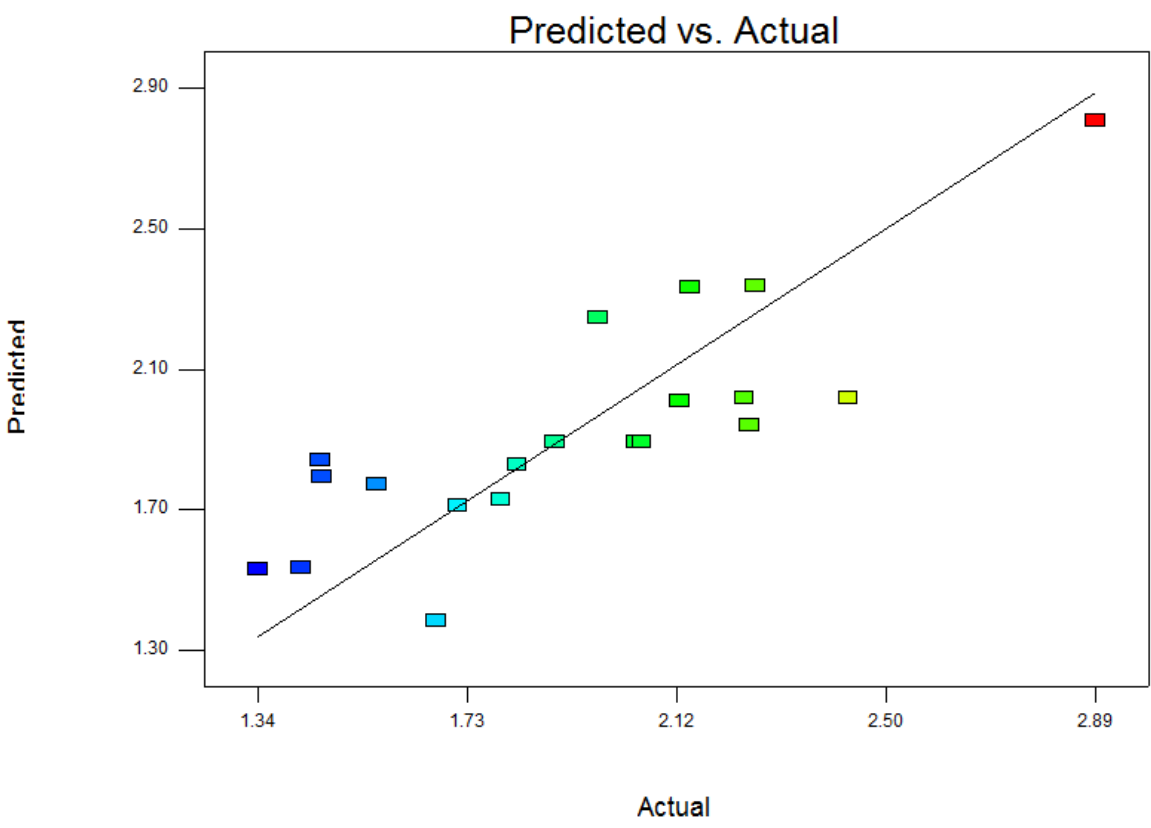

Fig.1 Relationship of Surface Response Methodology Actual and Prediction Value of Pectin Yield.

From the Design-Expert Software, the pectin yield can be seen in the normal residual plots in Figure 1 that the yield values are around 1.3 to $2.89 \%$. In Figure 1, it can be seen that the actual value of the research is approaching the straight line and partly a little distance from the straight line of pectin yield based on the value of the equation from the Software Expert System from the research that has been done. The actual research results, some are away from the straight line, but some are approaching the straight line. This shows that the study provides a fairly good precision value [19] .

Design-Expert® Software

Rendemen

2.89

1.34

$\mathrm{X} 1=\mathrm{A}: \mathrm{pH}$

$\mathrm{X} 2$ = B: Temparature

Actual Factor

C. Hours $=3.50$

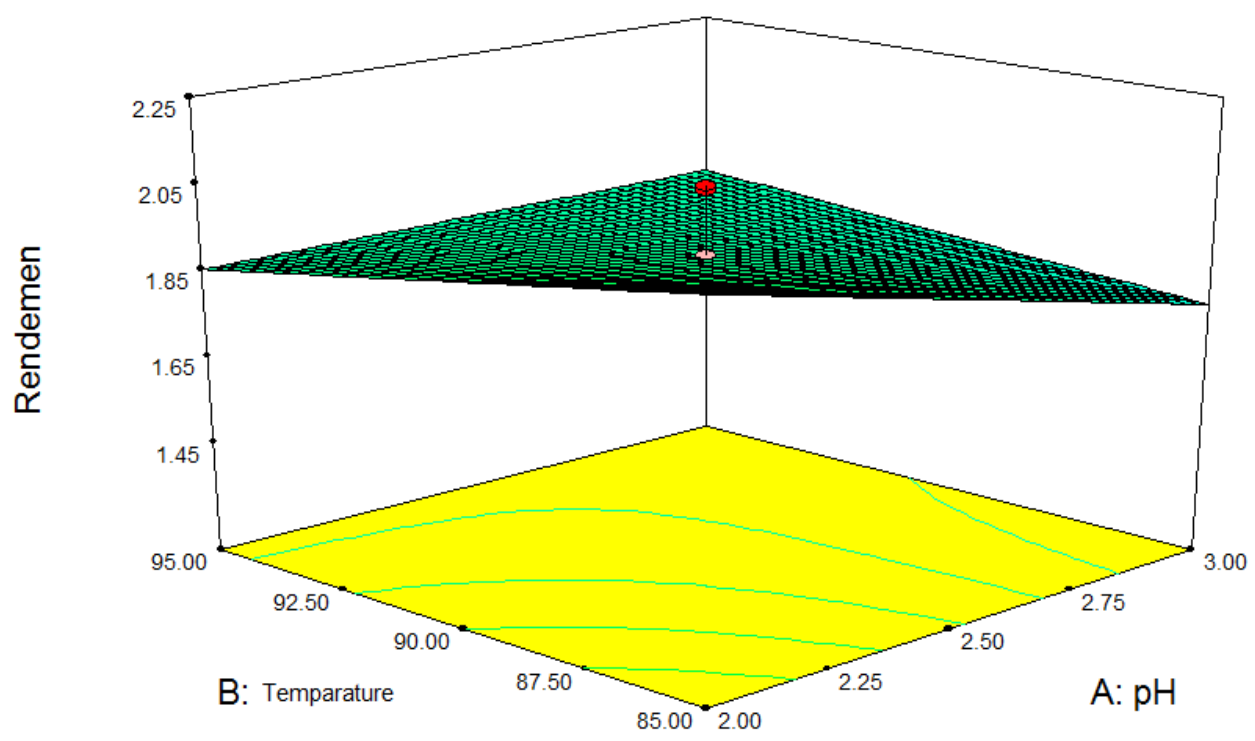

Fig. 2 The 3-D graph of the effect of $\mathrm{pH}$, temperature and extraction time on pectin yield from Responses surface methodology. 


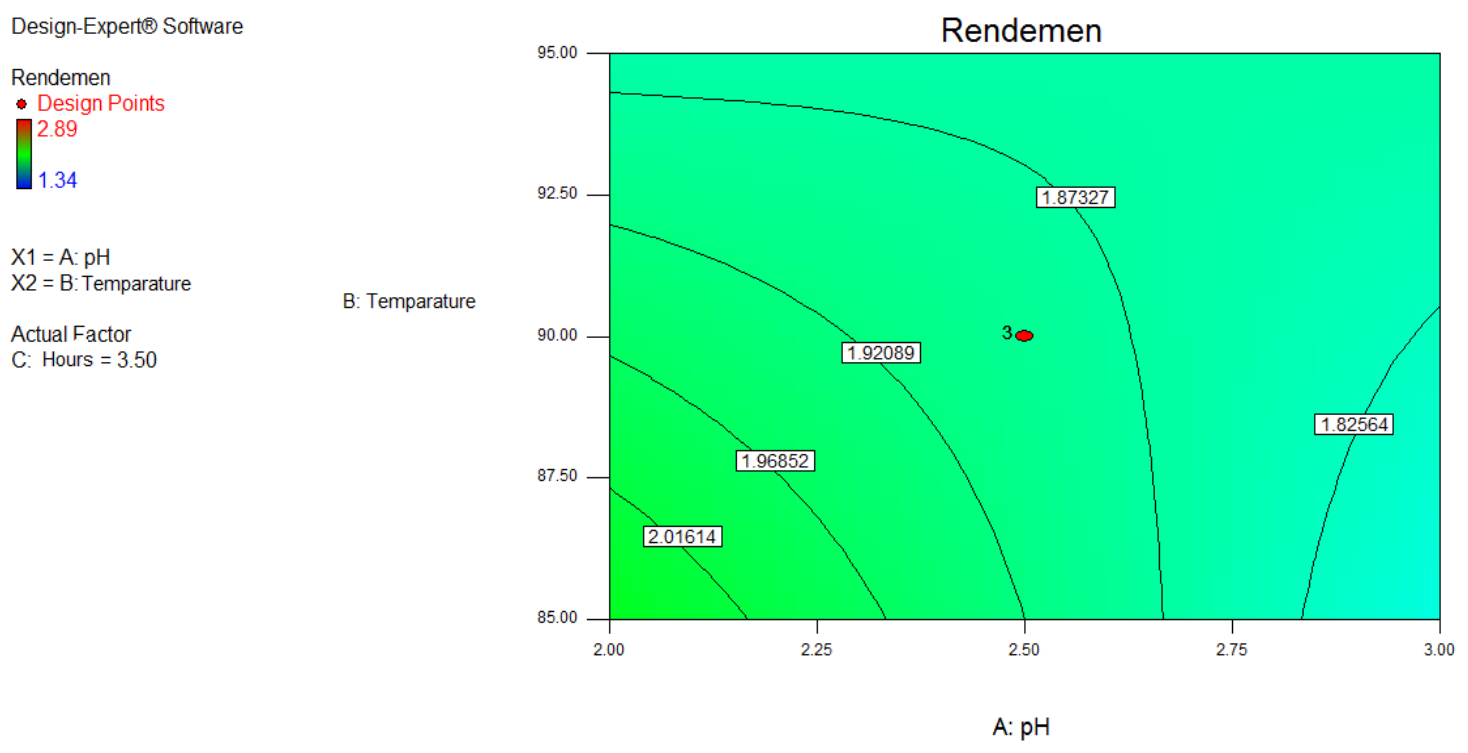

Fig.3 The 2-Dimensions of Response-Surface-Methodology contour, the influence of $\mathrm{pH}$, temperature and time to pectin yield.

Figures 2 and 3 show that $\mathrm{pH}$, temperature and extraction time of cocoa pod affect the yield of pectin produced. The lower the $\mathrm{pH}$, the higher the temperature and the longer the reaction, the higher the yield produced, until it reaches its optimal limit. The lower $\mathrm{pH}$ will destroy the cell wall because pectin dissolves in an acidic atmosphere so that pectin yield will increase. The higher the temperature, the pectin produced will also increase. The increase in temperature will increase the penetration of the solvent into the solid matrix (cocoa pod), thereby increasing the mass of polysaccharides that come out of the solid particles, thereby increasing the solubility of pectin until it reaches the optimal limit [17]. The extraction time affects the formation of pectin. Increasing the time of extraction will significantly increase the formation of pectin. The extraction time of 1.5-3 hours using citric acid solvent significantly increases pectin formation [14].

\section{Pectin Content}

The results of the analysis of variance (ANOVA) produced from the expert design program to obtain pectin content values can be seen in Table 5 .

TABLE V

RESUlts OF VARIANCE ANALYSIS (ANOVA) OF PECTIN CONTENTS

\begin{tabular}{|l|r|r|r|r|r|r|}
\hline Source & \multicolumn{1}{|c|}{$\begin{array}{l}\text { Sun of } \\
\text { Square }\end{array}$} & \multicolumn{1}{l|}{ df } & $\begin{array}{l}\text { Mean } \\
\text { Square }\end{array}$ & $\begin{array}{l}\text { F } \\
\text { Value }\end{array}$ & $\begin{array}{l}\text { p- } \\
\text { Value } \\
\text { Prob>F }\end{array}$ & \\
\hline Model & 1706.03 & 6 & 284.34 & 3.71 & 0.0226 & Significant \\
A-pH & 185.03 & 1 & 185.03 & 2.41 & 0.1443 & \\
B-Suhu & 19.35 & 1 & 19.35 & 0.25 & 0.6238 & \\
C- & 156.08 & 1 & 156.08 & 2.04 & 0.1773 & \\
Waktu & 66.33 & 1 & 66.33 & 0.86 & 0.3693 & \\
AB & 555.95 & 1 & 555.95 & 7.25 & 0.0185 & \\
AC & 101.55 & 1 & 101.55 & 1.32 & 0.2705 & \\
BC & 996.92 & 13 & 76.69 & & & Not \\
Residual & 817.75 & 10 & 81.77. & 1.37 & 0.4429 & significant \\
Lack of & 179.173 & 59.7 & & & & \\
Fit & 2702.95 & 19 & & & & \\
Pure & & & & & & \\
Error & & & & & & \\
Cor & & & & & & \\
Total & & & & & & \\
\hline
\end{tabular}

From Table 5 analysis of variance (ANOVA), it can be stated that the overall model of pectin extraction is significant for pectin content. Extraction parameters that significantly affect are the interaction of $\mathrm{pH}$ and the length of time of extraction. The lower the $\mathrm{pH}$ the more pectin is dissolved from the cell walls of raw materials that contain pectin. Low $\mathrm{pH}$ with longer extraction time will increase the soluble pectin and penetration due to the increase of solvent, this will increase the pectin content [17]. Pectin extraction will be influenced by $\mathrm{pH}$, temperature and time. At low temperatures, the occurrence of protopectin hydrolysis by acids is not maximum. Likewise, at low temperatures, the acidic atmosphere in short time hydrolysis of protopectin does not occur optimally, so that the formation of pectin will be low. Pectin consists of galacturonic acid or methyl ester units connected by $\alpha(1,4)$ glycosidic bonds. The glycosidic bond is a type of ether bond so that it can occur through the hydrolysis reaction under the right conditions, in this case, $\mathrm{pH}$, temperature and extraction time. The optimum conditions for pectin extraction are obtained at $90^{\circ} \mathrm{C}$, within 60 minutes [15]. The results of model selection based on lack of fit tests can be seen in Table 6 .

TABLE VI

Statistics Model for CocoA Pod EXTRACTION FOR PeCTin CONTENT RSM PROGRAM

\begin{tabular}{|c|c|c|c|c|c|c|}
\hline Source & $\begin{array}{l}\text { Std. } \\
\text { Dev. }\end{array}$ & $\begin{array}{l}\text { R- } \\
\text { Squared }\end{array}$ & $\begin{array}{l}\text { Adjusted } \\
\text { R- } \\
\text { Squared }\end{array}$ & $\begin{array}{l}\text { Predicted } \\
\text { R- } \\
\text { Squared }\end{array}$ & Press & \\
\hline Linier & 10.8 & 0.3373 & 0.2130 & -0.1315 & 3058.3 & \\
\hline $2 \mathrm{FI}$ & 8.76 & 0.6312 & 0.4609 & 0.1600 & 2270.4 & Suggested \\
\hline Quadratic & 9.67 & 0.6540 & 0.3426 & -0.5031 & 4062.8 & Aliased \\
\hline Cubic & 12.1 & 0.784 & -0.0241 & & + & \\
\hline
\end{tabular}

Table 6 of the statistical model Responses surface methodology program shows that among the existing models, namely linear, 2FI, quadratic, cubic, the recommended to be selected from processed design expert is 2FI, because the solution of maximum pectin yield selection is seen in the Adjusted R-Squared and Predicted R-Squared values. To get 
the equation of pectin content from pectin extraction research with optimization of $\mathrm{pH}$, temperature and time, the Responses surface methodology method is used [20]. The equation resulting from the optimization of extraction of pectin content by RSM method is:

$$
\begin{aligned}
\mathrm{Y}_{2}= & 79.90607-174.28035 \mathrm{X}_{1}+1.88569 \mathrm{X}_{2}+53.08067 \mathrm{X}_{3}+ \\
& 1.05640 \mathrm{X}_{1} \mathrm{X}_{2}+20.64326 \mathrm{X}_{1} \mathrm{X}_{3}-1.2777 \mathrm{X}_{2} \mathrm{X} 3
\end{aligned}
$$

Note: $\mathrm{Y}_{2}=$ Pectin levels, $\mathrm{X}_{1}=\mathrm{pH}, \mathrm{X}_{2}=$ temperature, $\mathrm{X}_{3}=$ time. Figure 4 shows the standard plot of the residual value of pectin content, which is between $10-60 \%$.
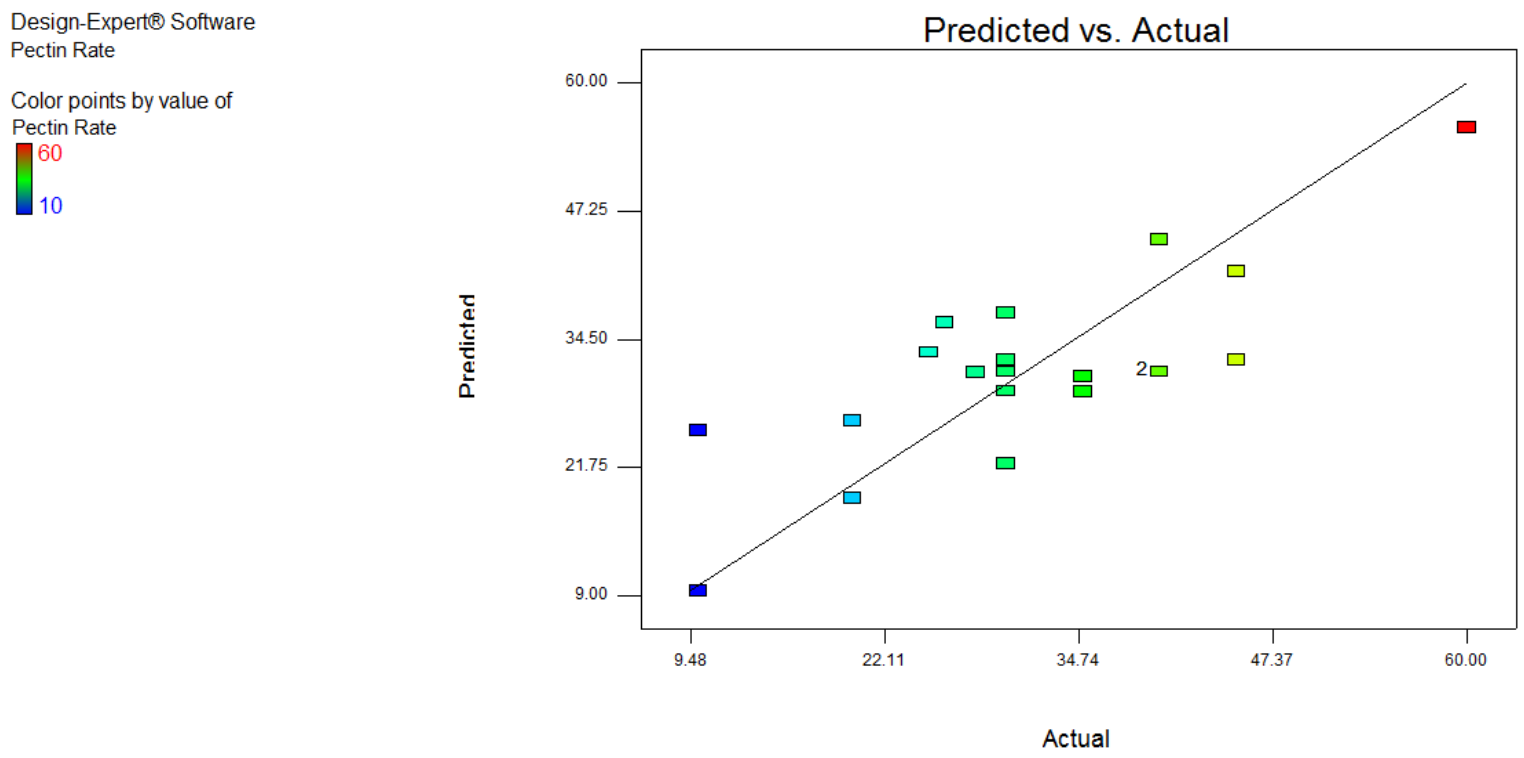

Fig.4 Relationship between Response Surface Methodology, Actual and Prediction Value of Pectin Content

Figure 4 on the graph shows that the cocoa pod extraction study for pectin content has a good precision. Some data obtained from research approach the straight line. Predictably, this research is good enough for the optimization of cocoa pod extraction against pectin content.
Obtained pectin content values spread from 10-60\%. The surface shape of the interaction between factors to the Responses of pectin content can be seen from the 3dimensional (3-D) graph in Figure 5.

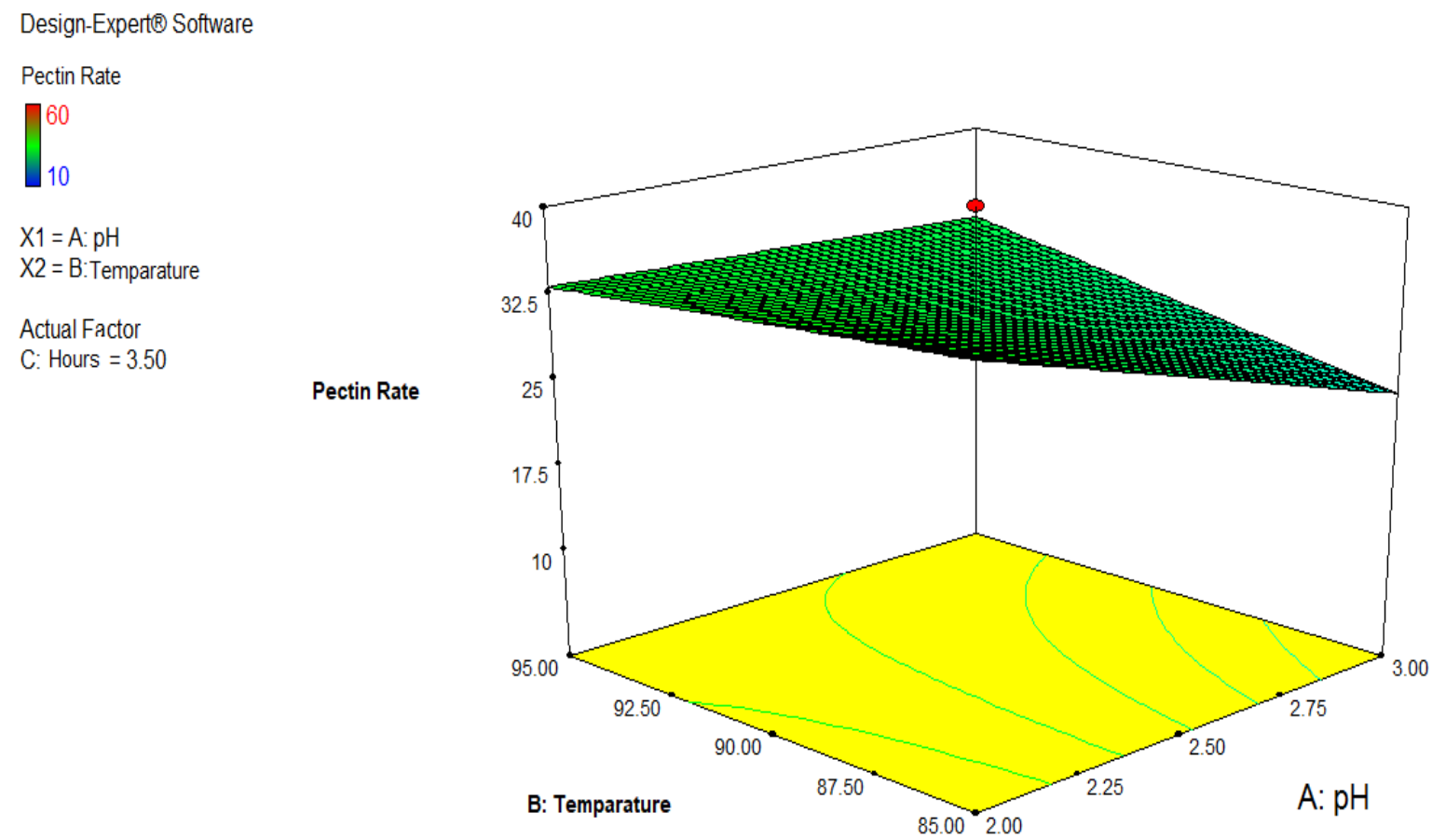

Fig.5 3-D graph of the effect of $\mathrm{pH}$, temperature and extraction time on pectin content from Responses surface methodology 


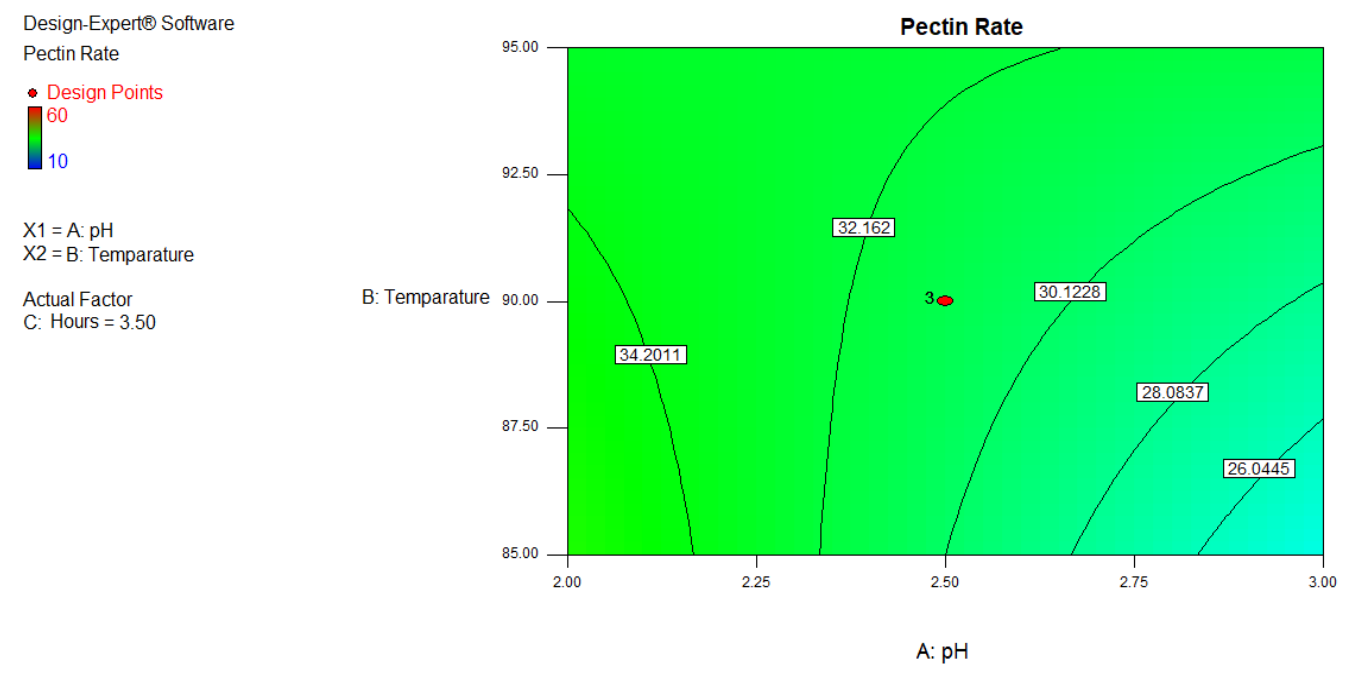

Fig. 62 Dimensions of Surface Response Methodology contour on the effect of $\mathrm{pH}$, temperature and extraction time on Pectin Content.

Figures 5 and 6 show that the $\mathrm{pH}$, temperature and extraction time of cocoa pod affect the amount of pectin significantly. The lower the $\mathrm{pH}$, the higher the temperature and the longer the reaction, the higher the pectin content produced until the optimal limit of the pectin content is reached. The effect of $\mathrm{pH}$ on pod extraction is that the lower the $\mathrm{pH}$ it will dissolve the pectin in the cell wall so that the pectin content will rise. The higher the temperature the more the solution will penetrate the solid matrix of the subtracted extracted so that the pectin content will increase. The extraction time also influences the pectin content produced. The longer the extraction time, the pectin levels produced are also increasing.

Overall, $\mathrm{pH}$, temperature and reaction time affect the level of pectin produced, until the optimal limit of the cocoa pod extraction process is reached. Temperature affects the solubility of the solute, it is in line with the extraction time. The solvent dissolves the substance during the extraction process. Increasing the temperature and the length of time causes the strength of hydrogen bonds in the water to be reduced so that it will increase the efficiency of the extraction process, this will increase the extraction result [18]. Extraction $\mathrm{pH}$ influences the level of pectin produced. The lower the $\mathrm{pH}$, the pectin dissolved in an acidic atmosphere is higher, until the optimum $\mathrm{pH}$ point [11].

\section{E. Methoxyl Content of Pectin}

In Table 7 can be seen as the results of the analysis of variance (ANOVA) of the methoxyl pectin content resulting from cocoa pod extraction after processing with the Design Expert Responses Surface Methodology Program as in Table 7. From Table 7, analysis of variance (ANOVA) can be seen that the model as a whole is significant. When viewed between the factors of $\mathrm{pH}$, temperature and time of cocoa pod extraction, only time has a significant effect on methoxyl content. Methoxyl content is the amount of methanol present in the pectin. Methanol content determines the gel properties of pectin. The formation of pectin gel is affected by the structure of the tissue of the pectin raw material source. Temperature also affects the properties of pectin; high temperatures will reduce the gel properties of pectin.
TABLE VII

RESULTS OF VARIANCE ANALYSIS (ANOVA) OF METOXYL CONTENT

\begin{tabular}{|l|r|r|r|r|r|r|}
\hline Source & $\begin{array}{r}\text { Sun of } \\
\text { Square }\end{array}$ & df & $\begin{array}{r}\text { Mean } \\
\text { Square }\end{array}$ & $\begin{array}{r}\mathrm{F} \\
\text { Value }\end{array}$ & $\begin{array}{r}\mathrm{p}- \\
\text { Value } \\
\text { Prob>F }\end{array}$ & \\
\hline Model & 17.26 & 9 & 1.92 & 4.86 & 0.0106 & Significant \\
A-pH & 0.56 & 1 & 0.56 & 1.42 & 0.2608 & $\mathrm{t}$ \\
B-Suhu & $2.82-\mathrm{E}-$ & 1 & $2.82 \mathrm{E}-$ & $7.15 \mathrm{E}-$ & 0.9343 & \\
C- & 003 & 1 & 003 & 003 & 0.0028 & \\
Waktu & 6.08 & 1 & 6.08 & 15.4 & 0.0520 & \\
AB & 1.92 & 1 & 1.92 & 4.86 & 0.3682 & \\
AC & 0.35 & 1 & 0.35 & 0.89 & 0.4131 & \\
BC & 0.29 & 1 & 0.29 & 0.73 & 0.0106 & \\
A2 & 3.88 & 1 & 3.88 & 9.83 & 0.0949 & \\
B2 & 1.34 & 1 & 1.34 & 3.40 & 0.5348 & Not \\
C2 & 0.16 & 10 & 0.16 & 0.41 & & significant \\
Residual & $3 . .95$ & 7 & 0.39 & & 06619 & \\
Lack of & 2.51 & 3 & 0.36 & 0.75 & & \\
Fit & 1.44 & 19 & 0.48 & & & \\
Pure & 21.21 & & & & & \\
Error & & & & & & \\
Cor & & & & & & \\
Total & & & & & & \\
& & & & & & \\
\hline
\end{tabular}

According to Ref. [21], the increasing temperature will reduce the formation of the gel properties of pectin. The temperatures above $50^{\circ} \mathrm{C}$ will decrease the gel properties of pectin. As the temperature increases, the pectin gel properties are also increasing, but with the subsequent increase in temperature will decrease the gel properties of pectin. At temperature $95^{\circ} \mathrm{C}$ indicated low pectin gel formation [22]. The results of selecting a statistical model for the pectin content from cocoa pod extraction can be seen in Table 8.

TABLE VIII

Statistical Model Of CocoA Pod EXTRACTION For PeCtin Methoxyl CONTENT RSM PROGRAM

\begin{tabular}{|l|l|l|l|l|l|l|}
\hline Source & $\begin{array}{l}\text { Std. } \\
\text { Dev. }\end{array}$ & $\begin{array}{l}\text { R- } \\
\text { Squared }\end{array}$ & $\begin{array}{l}\text { Adjusted } \\
\text { R- } \\
\text { Squared }\end{array}$ & $\begin{array}{l}\text { Predicted } \\
\text { R- } \\
\text { Squared }\end{array}$ & Press & \\
\hline Linier & 0.90 & 0.3887 & 0.2741 & 0.0096 & 21.01 & \\
2FI & 0.80 & 0.6034 & 0.4204 & 0.0996 & 19.10 & \\
Quadratic & $\underline{0.63}$ & $\underline{0.8138}$ & $\underline{0.6463}$ & $\underline{0.3610}$ & 13.55 & $\begin{array}{l}\text { Suggested } \\
\text { Aliased }\end{array}$ \\
\hline Cubic & 0.64 & 0.9217 & 0.6278 & & + & \\
\hline
\end{tabular}


In Table 8 of the statistical Responses surface methodology model, that among the existing models, namely linear, 2FI, quadratic, cubic, the quadratic is chosen. The quadratic model is chosen after selecting the maximum solution to the program and the maximum Adjusted $R$ Squared and Predicted $R$-Squared values. The equation generated from the extraction optimization to the pectin methoxyl content by Responses surface methodology method is:

$$
\begin{aligned}
\mathrm{Y}_{3}= & -171.36095+24.19204 \mathrm{X}_{1}+3.11379 \mathrm{X}_{2}+5.83537 \mathrm{X}_{3}- \\
& 0.18338 \mathrm{X} 1 \mathrm{X} 2+0.56883 \mathrm{X}_{1} \mathrm{X} 3-0.067311 \mathrm{X}_{2} \mathrm{X}_{3}- \\
& 2.01272\left(\mathrm{X}_{1}\right)^{2}-0.013459\left(\mathrm{X}_{2}\right)^{2}-0.34831\left(\mathrm{X}_{3}\right)^{2}
\end{aligned}
$$

From the design expert software of cacao pod extraction to pectin, methoxyl content can be seen in the standard residual plot in Figure 7.

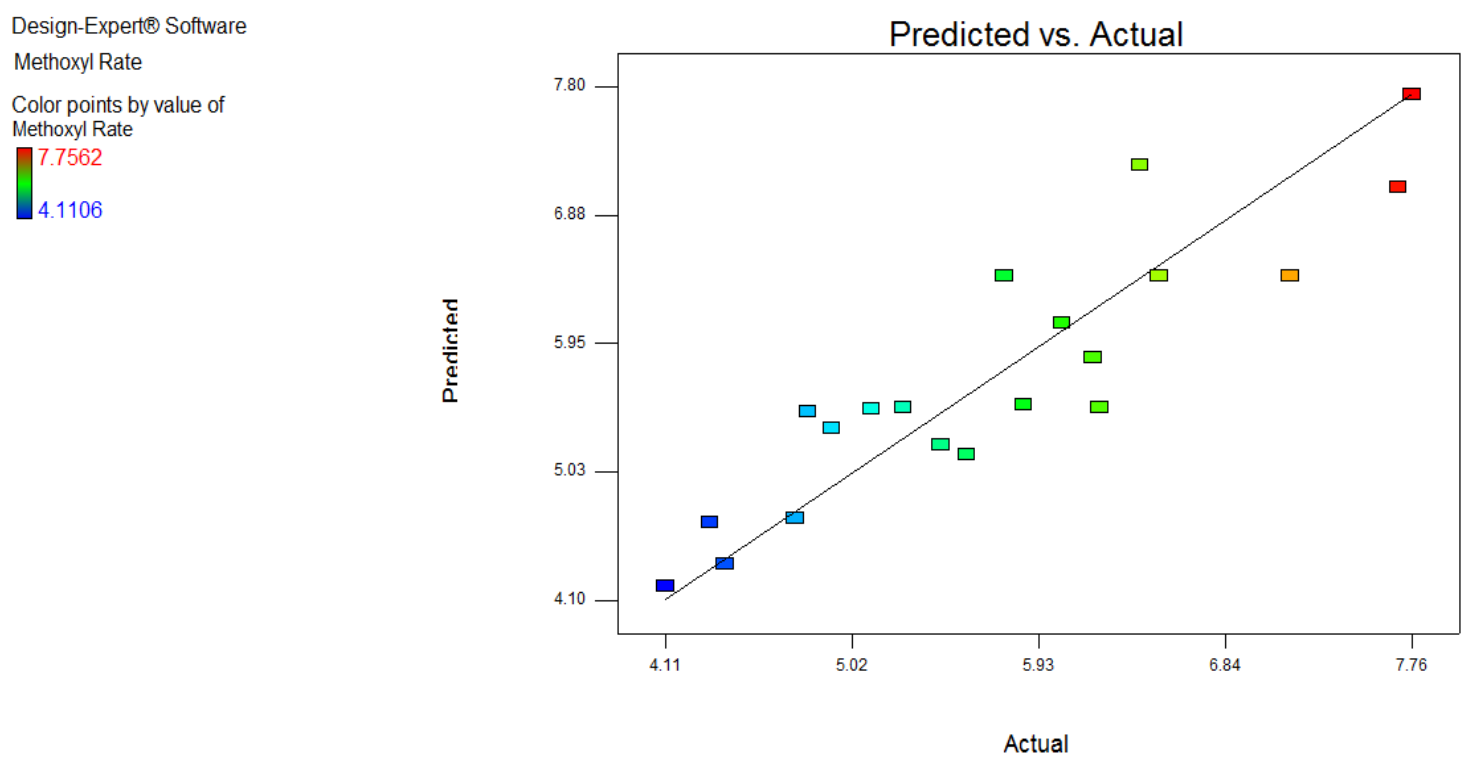

Fig. 7 Relationship between Response Surface Methodology, Actual and Prediction value of Pectin Methoxyl Content

Figure 7 shows that the value of pectin methoxyl content based on the value of the equation obtained from the calculation of Expert System software and the results of actual research. Many of the research actual results approaching the straight line, although some are a bit far from the straight line, it shows that the research shows a reasonably good precision value. Based on the equation obtained that the value of the pectin methoxyl content is at $4.1106-7.7562 \%$. Figures 8 and 9 show the surface Responses and contour Responses from the extraction optimization carried out on the cocoa pod pectin content. Figures 8 and 9 show that $\mathrm{pH}$, temperature and extraction time of cocoa pod affect the pectin content produced.

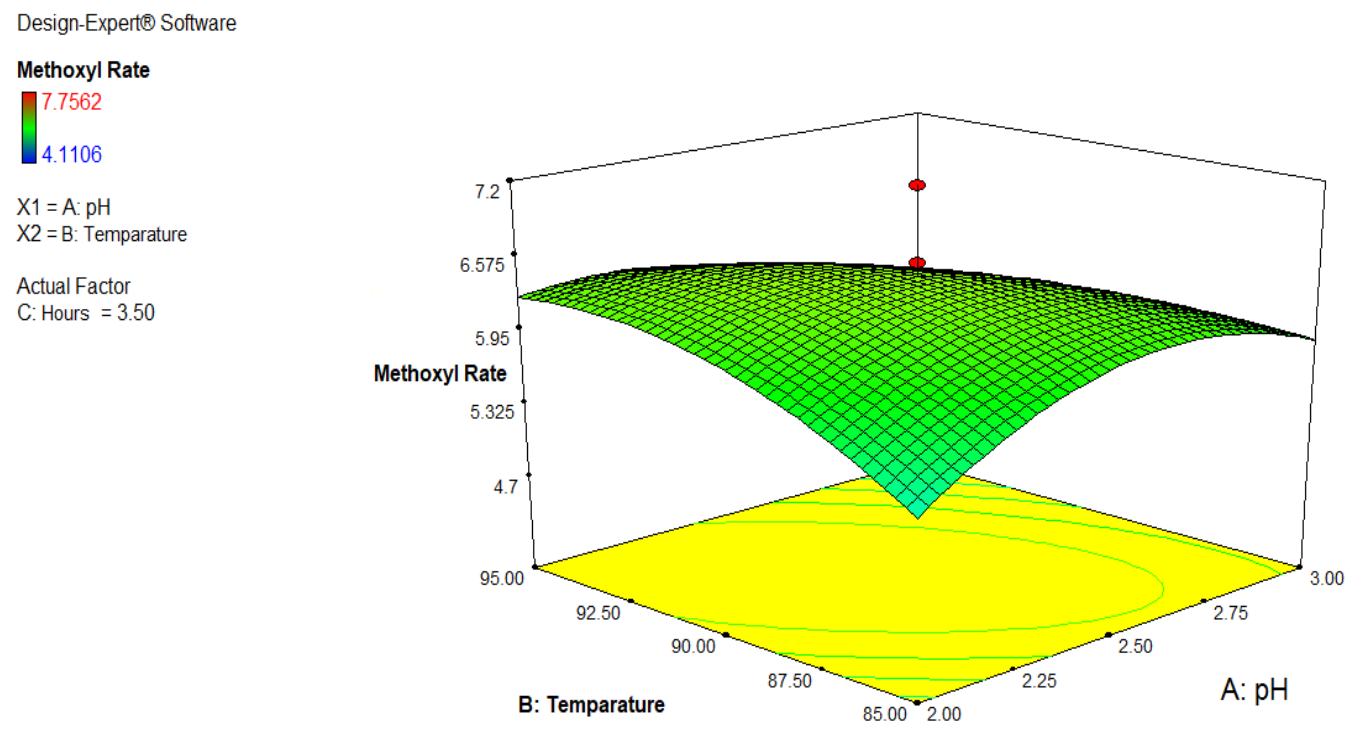

Fig. 8 3-D graph for the effect of $\mathrm{pH}$, temperature and extraction time on pectin methoxyl content from the Responses surface methodology 

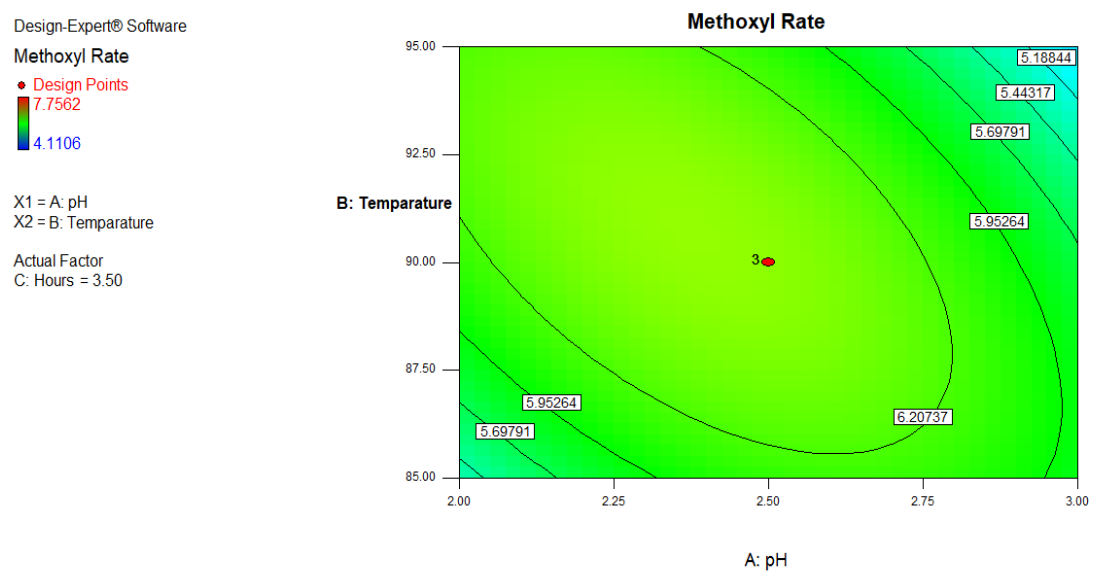

Fig. 92 Dimensions Contour of Surface Responses Methodology for the effect of $\mathrm{pH}$, temperature and extraction time on pectin methoxyl content.

The surface shape of the interaction relationship between $\mathrm{pH}$, temperature and time is seen in the 3-D graph (Figure 8) and the 2-dimensional contour graph (Figure 9) shows that the lower the $\mathrm{pH}$, the higher the temperature, and the longer the time, will produce higher methoxyl content until it reaches a certain point. After reaching the optimal point, the effect of $\mathrm{pH}$, temperature and time is no longer increases the pectin methoxyl content. Low $\mathrm{pH}$, the interaction between temperature and reaction time, will give higher methoxyl properties until the optimal limit. [21] and [22] states that $\mathrm{pH}$ and temperature greatly affect the methoxyl content produced, so do with the length of extraction time, until it reaches its optimal point. According to IPPA quality standards, the amount of methoxyl produced is classified as low methoxyl content, which is less than $7 \%$. There are only 3 treatments that have more than $7 \%$ of methoxyl content.

\section{F. Optimization Solution from Design Expert on the Pectin Yield}

An optimization solution to determine the optimal point from RSM program is obtained by determining the variable criteria of the desired Responses. The criteria of the desired Responses for pectin yield, pectin content and methoxyl content are maximum. The results of the program solution show that optimal extraction at $\mathrm{pH} 2$, temperature $95^{\circ} \mathrm{C}$, extraction time 3 hours with $2.33 \%$ pectin yield, $44.39 \%$ pectin content and $7.08 \%$ methoxyl content and 0.71 desirability value [23]. Then after verification, the results obtained are $2.16 \%$ pectin yield, $45 \%$ pectin content, $8.99 \%$ methoxyl content. There is no significant difference between the value of optimal condition prediction of RSM program and the verification results, so the results of the expert program design software from the Responses surface methodology with the central composite design can be accepted to be used in the cocoa pod pectin extraction process to obtain optimal pectin yield, pectin content and methoxyl content [24].

\section{G. FTIR (Fourier Transform Infrared) Analysis}

Analysis of FTIR (Fourier Transform Infra-Red) of dried pectin that has been blended, mixed with $\mathrm{KBr}$, made into pellets then analyzed using FTIR spectrophotometer.

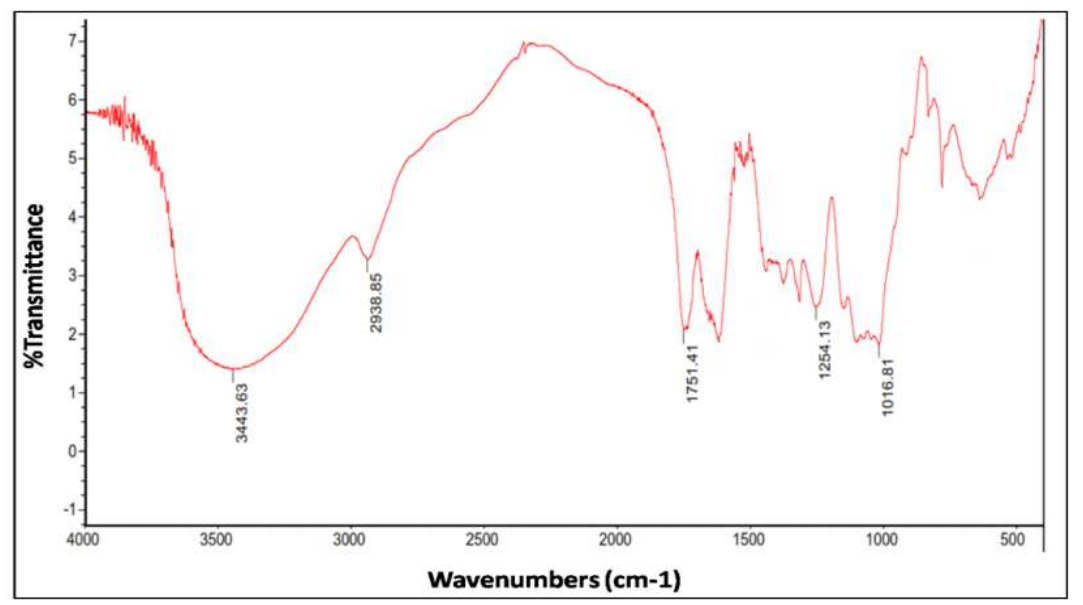

Fig. 10 The best RSM spectrum

The spectrum is interpreted to determine the functional groups contained in the pectin. A bond in a molecule that absorbs infrared radiation will vibrate. The amount of absorption in a particular type of bond depends on the type of vibration of the bond. Therefore, different types of bonds absorb infrared radiation at different characteristic wavelengths. The results of the standard pectin FTIR spectrum and the cocoa pod pectin can be seen in Figure 10. The functional groups between the standard pectin and the cocoa skin pectin are not significantly different, they both have the same variety of functional groups. The IR spectrum of the cocoa pod (Figure 10), shows the absorption area of 
various functional groups. In the absorption band 3443.63 $\mathrm{cm}^{-1}$ shows the absorption peak intensity is very strong and wide, it indicates the presence of $\mathrm{O}-\mathrm{H}$ strain absorption. The absorption band $2938.85 \mathrm{~cm}^{-1}$ shows the absorption of the C$\mathrm{H}$ strain. The absorption band $1751.41 \mathrm{~cm}^{-1}$ shows the absorption of $\mathrm{C}=\mathrm{O}$ strain which is thought to originate from the carboxyl group of carboxylic acids which is supported by a very wide $\mathrm{O}-\mathrm{H}$ absorption band due to hydrogen bonding with its dimer. Absorption at $1254.13 \mathrm{~cm}^{-1}$ shows C-O-C absorption and $1016.81 \mathrm{~cm}^{-1}$ represents symmetric C-O-C absorption (on glycosides bonds) [25]. This data supports that the isolated pectin has the structure shown in Figure 10.

\section{IV.CONCLUSION}

This research showed that the length of extraction and the interaction between $\mathrm{pH}$ and the length of extraction, significantly affect the pectin yield, and the interaction between $\mathrm{pH}$ and the duration of heating time on extraction have a significant effect on the content of pectin, and the interaction between $\mathrm{pH}$ and time significantly affects the methoxyl content of pectin. Overall, $\mathrm{pH}$, temperature and extraction time of cocoa pod are significantly affecting the yield, pectin content and methoxyl content. The optimum conditions for extracting cocoa pod pectin with Responses surface methodology are $\mathrm{pH} 2$, temperature $95^{\circ} \mathrm{C}$ and extraction time 3 hours with predicted pectin yield $2.33 \%$ pectin content $44.39 \%$ and methoxyl content $7.08 \%$. After verification, the result is pectin yield $2.16 \%$, pectin content $45 \%$ and methoxyl content $8.99 \%$. The significant difference between the prediction of the program and the results of verification means that the optimal process of extracting cocoa pod pectin is acceptable. From FTIR test of pectin, it is known that the absorption band $3443.63 \mathrm{~cm}^{-1}$ shows a very strong and wide absorption peak intensity, the presence of O-H absorption, strain. The absorption band $2938.85 \mathrm{~cm}^{-1}$ shows the absorption of $\mathrm{C}-\mathrm{H}$ strain. The absorption band $1751.41 \mathrm{~cm}^{-1}$ shows the absorption of $\mathrm{C}=\mathrm{O}$ strain which is thought to originate from the carboxyl group of carboxylic acids which is supported by an extensive O-H absorption band due to the presence of hydrogenic bonds with its dimers. Absorption at $1254.13 \mathrm{~cm}^{-1}$ shows the absorption of $\mathrm{C}-\mathrm{O}-\mathrm{C}$ and $1016.81 \mathrm{~cm}^{-1}$ represents symmetric $\mathrm{C}-\mathrm{O}-\mathrm{C}$ absorption (on glycosides bonds)

\section{REFERENCES}

[1] F. Fioresi et al., "Chemical modification of the cocoa shell surface using diazonium salts," J. Colloid Interface Sci., vol. 494, pp. 92-97, 2017

[2] Y. Chen, J. G. Zhang, H. J. Sun, and Z. J. Wei, "Pectin from Abelmoschus esculentus: Optimization of extraction and rheological properties," Int. J. Biol. Macromol., vol. 70, pp. 498-505, 2014.

[3] S. Khanahmadi, F. Yusof, H. Chyuan Ong, A. Amid, and H. Shah, "Cocoa pod husk: A new source of CLEA-lipase for preparation of low-cost biodiesel: An optimized process," J. Biotechnol., vol. 231, pp. 95-105, 2016.

[4] M. D. G. De Luna, Murniati, W. Budianta, K. K. P. Rivera, and R. O. Arazo, "Removal of sodium diclofenac from aqueous solution by adsorbents derived from cocoa pod husks," J. Environ. Chem. Eng., vol. 5, no. 2, pp. 1465-1474, 2017.

[5] P. Judith et al., "Food Hydrocolloids Edible fi lms from pectin: Physical-mechanical and antimicrobial properties - A review," vol. $35,2014$.
[6] R. M. Zaid, P. Mishra, S. Tabassum, Z. A. Wahid, and A. M. M. Sakinah, "High methoxyl pectin extracts from Hylocereus polyrhizus's peels: Extraction kinetics and thermodynamic studies," Int. J. Biol. Macromol., 2019.

[7] F. Priyangini, S. G. Walde, and R. Chidambaram, "Extraction optimization of pectin from cocoa pod husks (Theobroma cacao L.) with ascorbic acid using response surface methodology," Carbohydr. Polym., vol. 202, pp. 497-503, 2018.

[8] A. M. Idrovo Encalada et al., "High-power ultrasound pretreatment for efficient extraction of fractions enriched in pectins and antioxidants from discarded carrots (Daucus carota L.)," J. Food Eng., vol. 256, pp. 28-36, 2019.

[9] B. Utomo, A. A. Prawoto, S. Bonnet, A. Bangviwat, and S. H. Gheewala, "Environmental performance of cocoa production from monoculture and agroforestry systems in Indonesia," J. Clean. Prod., vol. 134, no. Part B, pp. 583-591, 2016.

[10] S. S. Hosseini, F. Khodaiyan, and M. S. Yarmand, "Aqueous extraction of pectin from sour orange peel and its preliminary physicochemical properties," Int. J. Biol. Macromol., vol. 82, pp. 920-926, 2016.

[11] P. H. F. Pereira et al., "Pectin extraction from pomegranate peels with citric acid," Int. J. Biol. Macromol., vol. 88, pp. 373-379, 2016.

[12] C. Colodel, L. C. Vriesmann, R. F. Teófilo, and C. L. de Oliveira Petkowicz, "Extraction of pectin from ponkan (Citrus reticulata Blanco cv. Ponkan) peel: Optimization and structural characterization," Int. J. Biol. Macromol., vol. 117, pp. 385-391, 2018.

[13] R. F. Caroço, B. Kim, P. A. Santacoloma, J. Abildskov, J. H. Lee, and J. K. Huusom, "Analysis and model-based optimization of a pectin extraction process," J. Food Eng., vol. 244, pp. 159-169, 2019.

[14] S. Y. Chan and W. S. Choo, "Effect of extraction conditions on the yield and chemical properties of pectin from cocoa husks," Food Chem., vol. 141, no. 4, pp. 3752-3758, 2013.

[15] A. A. Sundarraj, R. Thottiam Vasudevan, and G. Sriramulu, "Optimized extraction and characterization of pectin from jackfruit (Artocarpus integer) wastes using response surface methodology," Int. J. Biol. Macromol., vol. 106, pp. 698-703, 2018.

[16] C. Li, Q. Xiao, Y. Tang, and L. Li, "A method integrating Taguchi, RSM and MOPSO to CNC machining parameters optimization for energy saving," J. Clean. Prod., vol. 135, pp. 263-275, 2016.

[17] J. Lu, J. Li, R. Jin, S. Li, J. Yi, and J. Huang, "Extraction and characterization of pectin from Premna microphylla Turcz leaves,' Int. J. Biol. Macromol., vol. 131, pp. 323-328, 2019.

[18] S. Q. Liew, W. H. Teoh, C. K. Tan, R. Yusoff, and G. C. Ngoh, "Subcritical water extraction of low methoxyl pectin from pomelo (Citrus grandis (L.) Osbeck) peels," Int. J. Biol. Macromol., vol. 116, pp. 128-135, 2018.

[19] Z. Raji, F. Khodaiyan, K. Rezaei, H. Kiani, and S. S. Hosseini, "Extraction optimization and physicochemical properties of pectin from melon peel," Int. J. Biol. Macromol., vol. 98, pp. 709-716, 2017.

[20] M. Abid, C. M. G. C. Renard, A. A. Watrelot, I. Fendri, H. Attia, and M. A. Ayadi, "Yield and composition of pectin extracted from Tunisian pomegranate peel," Int. J. Biol. Macromol., vol. 93, pp. 186-194, 2016.

[21] J. Zheng, R. Zeng, J. Kan, and F. Zhang, "Effects of ultrasonic treatment on gel rheological properties and gel formation of highmethoxyl pectin," J. Food Eng., vol. 231, pp. 83-90, 2018.

[22] W. Wang et al., "Applications of power ultrasound in oriented modification and degradation of pectin: A review," J. Food Eng., vol. 234, pp. 98-107, 2018.

[23] X. Zhai, C. Zhu, Y. Li, Y. Zhang, Z. Duan, and X. Yang, "Optimization for pectinase-assisted extraction of polysaccharides from pomegranate peel with chemical composition and antioxidant activity," Int. J. Biol. Macromol., vol. 109, pp. 244-253, 2018.

[24] I. G. Moorthy, J. P. Maran, S. M. Surya, S. Naganyashree, and C. S. Shivamathi, "Response surface optimization of ultrasound assisted extraction of pectin from pomegranate peel," Int. J. Biol. Macromol., vol. 72, pp. 1323-1328, 2015.

[25] C. N. Tejada-tovar and A. Villabona-ortiz, "Evaluation of Theobroma cacao Waste Performance in Nickel Removal (II) in Continuous System*," Int. J. ChemTech Res., vol. 11, no. 05, pp. 186-194, 2018. 